\title{
New Carbonylation Reaction of Tungsten-Propargyl Compounds via Protonation at a Prolonged Period
}

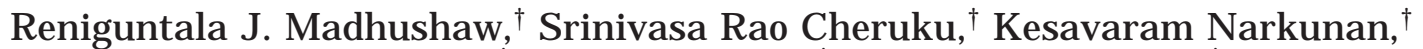 \\ Gene-Hsian Lee, ${ }^{\ddagger}$ Shie-Ming Peng, ${ }^{\ddagger}$ and Rai-Shung Liu*,† \\ Department of Chemistry, National Tsing-Hua University, Hsinchu, 30043, Taiwan, ROC, and \\ Department of Chemistry, National Taiwan University, Taipei, 10764, Taiwan, ROC
}

Received September 21, 1998

\begin{abstract}
The $\mathrm{CpW}(\mathrm{CO})_{3}\left(\eta^{1}-\mathrm{CH}_{2} \mathrm{C} \equiv \mathrm{CR}\right)(\mathrm{R}=\mathrm{Me} \mathrm{1}, \mathrm{Ph} 2)$ complexes were treated with triflic acid (2.0 equiv) in cold dichloromethane $\left(-78{ }^{\circ} \mathrm{C}\right)$, and after a long period to the mixture was added water or $\mathrm{RNH}_{2}$ to give good yields of carbonylation products $\mathrm{CpW}(\mathrm{CO})_{2}\left(\eta^{1}, \eta^{2}-\mathrm{CH}_{2^{-}}\right.$ $\mathrm{CHCHR}-\mathrm{Y}-\mathrm{CO}-)(\mathrm{R}=\mathrm{Me}, \mathrm{Ph} ; \mathrm{Y}=\mathrm{RN}, \mathrm{O})$. These products were fully characterized by appropriate physical methods including single-crystal X-ray diffraction. If a chiral amine such as (R)-methylbenzylamine was used in the reaction, two optically active isomers in equal proportions were obtained and further separated on a silica column. In the case of $\left(\mathrm{C}_{5} \mathrm{Me}_{5}\right) \mathrm{W}(\mathrm{CO})_{3}\left(\eta^{1}-\mathrm{CH}_{2} \mathrm{C} \equiv \mathrm{CPh}\right)(\mathbf{9})$, its reactions with triflic acid and water in the same reaction sequence produce $\left(\mathrm{C}_{5} \mathrm{Me}_{5}\right) \mathrm{W}(\mathrm{CO})_{2}\left(\eta^{1}, \eta^{2}-\mathrm{CH}_{2} \mathrm{CHCHPh}-\mathrm{O}-\mathrm{CO}-\right)$ as two diastereomers which undergo mutual exchange according to variable-temperature ${ }^{1} \mathrm{H}$ NMR spectroscopy.
\end{abstract}

\section{Introduction}

The action of a metal- $-\eta^{1}$-unsaturated hydrocarbyl compound with a strong acid is a general method for generation of metal $-\eta^{2}$-carbocations. ${ }^{1,2}$ Scheme 1 (eq 1) shows three representative examples of formation of metal $-\eta^{2}$-alkene ${ }^{3}(\mathbf{A}),-\eta^{2}$-allene ${ }^{4}(\mathbf{B})$, and $-\eta^{1}$ vinylidene ${ }^{5}(\mathbf{C})$ carbocations via protonation of their corresponding allyl, propargyl, and alkynyl compounds. Recently, we discovered 6 that protonation of tungsten$\eta^{1}$-alkynyl complexes in a prolonged reaction period

† National Tsing-Hua University.

₹ National Taiwan University.

(1) Review papers: (a) Norton, J. R. In Inorganic Reactions and Methods; Verlag Chemie: Weinheim, 1987. (b) Pearson, R. G. Chem Rev. 1985, 85, 41.

(2) (a) Collman, J. P.; Hegedus, L. S.; Norton, J . R.; Finke, R. G Principles and Application of Organotransition Metal Chemistry University Science Books: Mill Valley, CA, 1987; Chapter 8, p 433. (b) Hegedus, L. S. Transition Metals in the Synthesis of Complex Organic Molecules; University Science Books: Mill Valley, 1994; Chapter 2, p 43

(3) Organic Syntheses via metal $-\eta^{2}$-alkene cations, see representative papers: (a) Welker, M. E. Chem. Rev. 1992, 92, 97. (b) J iang, S. Turos, E. Organometallics 1993, 12, 4280. (c) J iang, S.; Turos, E. Tetrahedron Lett. 1991, 4639. (d) Rosenblum, M.; Watkins, J . C. J Am. Chem. Soc. 1990, 112, 6316. (e) Bell, P. B.; Wojcicki, A. Inorg. Chem. 1981, 20, 1585.

(4) Organic Syntheses via metal $-\eta^{2}$-allene cations, see representative papers: (a) Bell, P. B.; Wojcicki, A. Inorg. Chem. 1981, 20, 1585 (b) Raghu, S.; Rosenblum, M. J. Am. Chem. Soc. 1973, 95, 3060. (c) Blosser, P. W.; Shimpff, D. G.; Gallucci, J . C.; Wojcicki, A. Organome tallics 1993, 12, 2, 1393. (d) Chen, C.-C.; Fan J .-S.; Shieh, S.-J .; Lee G.-H.; Peng, S.-M.; Wang, S.-L.; Liu, R.-S. J . Am. Chem. Soc. 1996 118, 9279. (e) Benaim, J.; Merour, J .-Y.; Roustan, J. L. C. R. Acad. Sci. Paris, Ser. C 1971, 272, 789.

(5) Organic Syntheses via metal $-\eta^{1}$-vinylidene cations, see repre sentative papers: (a) Bruce, M. I. Chem. Rev. 1991, 91, 257. (b) Trost, B. M.; Dyker, G.; Kulawiec, R. J . J . Am. Chem. Soc. 1990, 112, 7809. (c) Trost, B. M.; Martinez, J. A.; Indolese, A. F. J . Am. Chem. Soc. 1993, 115, 10402. (d) Trost B. M.; Flygare, J. A. J . Am. Chem. Soc. 1992, 114, 5467. (e) McDonald, F. E.; Bowman, J . L. Tetrahedron Lett. 1996, 4675. (f) McDonald, F. E.; Schultz, C. C. J . Am. Chem. Soc. 1994 116, 9363.

(6) Liang, K.-W.; Chandrasekharam, M.; Li, C.-L.; Liu, R.-S. Organometallics 1998, 17, 2683.

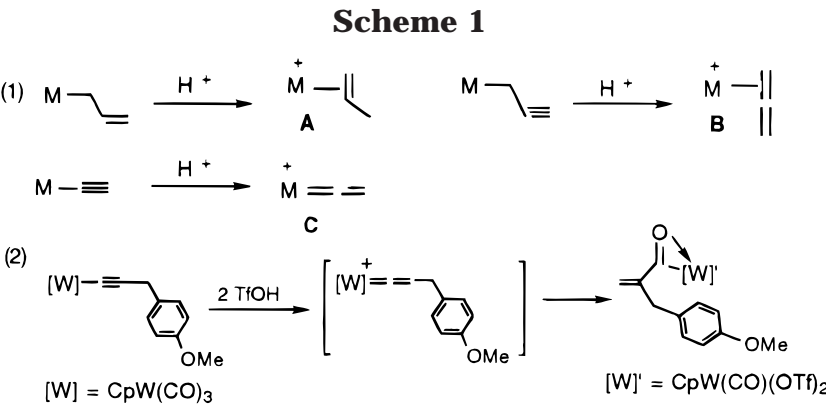

ultimately led to an oxidative carbonylation reaction to give tungsten(IV) acyl complexes via a tungsten(II)$\eta^{1}$-vinylidene intermediate, as shown in Scheme 1 (eq 2). This observation raises an interesting question regarding the kinetic stabilities of the other two carbocations ( $\mathbf{A}$ and $\mathbf{B}$ ) in a prolonged reaction period; this issue has not been studied thoroughly. In this article, we study the reaction chemistry of tungsten $-\eta^{1}$-propargyl complexes $\mathrm{CpW}(\mathrm{CO})_{3}\left(\eta^{1}-\mathrm{CH}_{2} \mathrm{C} \equiv \mathrm{CR}\right)(\mathrm{R}=\mathrm{Me} \mathrm{1}$, $\mathrm{Ph}$ 2) after protonation over different periods, and the effect of reaction time on the chemical reactivity of the resulting tungsten $-\eta^{2}$-allene cation (B) will be reported in detail.

\section{Results and Discussion}

It was previously reported 7,8 that treatment of tungsten-propargyl compounds such as $\mathbf{1}$ and $\mathbf{2}$ with triflic

(7) (a) Rosenblum, M.; Raghu, S. J . Am. Chem. Soc. 1973, 95, 3062 (b) Lichtenberg, D. L.; Wojcicki, A. J . Organomet. Chem. 1975, 94, 311. (c) Charrier, C.; Coll in, J .; Merour, J. Y.; Roustan, J . L. J . Organomet. Chem. 1978, 162, 57. (d) Giulieri, F.; Benaim, J. Organomet. Chem. 1978, 162, 57

(8) (a) Lin, S. H.; Vong, W. J .: Liu, R. S. Organometallics 1995, 14, 1619. (b) Chen, C.-H. Fan, J .-S.; Lee, G.-H.; Shieh, S.-J .; Wang, S.-L.; Peng S.-M.; Liu, R.-S. J . Am. Chem. Soc. 1996, 118, 9279. (c) Shiu, L. H.; Wang S.-L.; Wu M.-J .; Liu R. S. J. Chem. Soc., Chem. Commun. 1997, 2005. (d) Cheng, M.-H.; Ho, Y.-H.; Lee, G.-H.; Peng, S.-M.; Chu, S.-Y.; Liu, R.-S. Organometallics 1994, 13, 4082. 


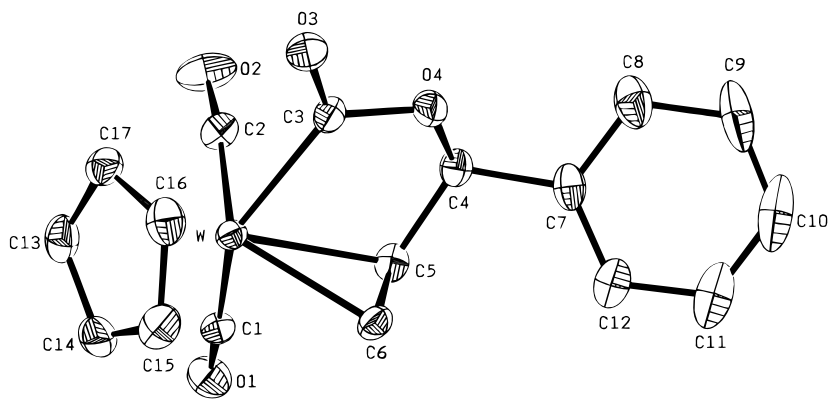

Figure 1. Molecular structure of compound 5 with selected bond distances $(\AA)$ and angles (deg): $\mathrm{W}-\mathrm{C}(3)=2.211(6)$, $\mathrm{W}-\mathrm{C}(5)=2.288(6), \mathrm{W}-\mathrm{C}(6)=2.250(6), \mathrm{C}(3)-\mathrm{O}(3)=1.204$ (7), $\mathrm{C}(4)-\mathrm{O}(4)=1.427(7), \mathrm{C}(4)-\mathrm{C}(5)=1.514(9), \mathrm{C}(5)-\mathrm{C}(6)$ $=1.402(8)$.

acid $\left(\mathrm{CF}_{3} \mathrm{SO}_{3} \mathrm{H}\right)$ in cold $\mathrm{CH}_{2} \mathrm{Cl}_{2}\left(-78{ }^{\circ} \mathrm{C}\right)$ followed by immediate addition of water, alcohol, and amine led to al koxycarbonylation reaction to yield syn- $\pi$-2-carboxylated allyl complexes 3. According to the chemistry of related $\mathrm{CpFe}(\mathrm{CO})_{2}\left(\eta^{1}-\mathrm{CH}_{2} \mathrm{C} \equiv \mathrm{CR}\right)$ complexes, ${ }^{7}$ formation of $\mathbf{3}$ can be envisaged to originate from the cis- $\eta^{2}$-allene intermediate (D), of which the CO group is initially attacked by $\mathrm{YXH}\left(\mathrm{YX}=\mathrm{HO}, \mathrm{RO}, \mathrm{R}_{2} \mathrm{~N}\right)$ to form species $\mathbf{E}$; further insertion of the $\mathrm{W}-\mathrm{COXY}$ bond of $\mathbf{E}$ into its central allene carbon generates the syn-isomer of $\mathbf{3}$. To study the effect of reaction time on the chemical reactivity of tungsten $-\eta^{2}$-allene cation $\mathbf{D}$, the solution was warmed to $23{ }^{\circ} \mathrm{C}$ in a period of $10 \mathrm{~h}$ before treatment of water or $\mathrm{R}^{\prime} \mathrm{NH}_{2}\left(\mathrm{R}^{\prime}=\mathrm{Bu}^{\mathrm{i}}, \mathrm{PhCH}_{2}\right)$. After workup of the solution, the new organometallic products 4-7 show NMR spectral data distinct from those expected for tungsten-syn- $\pi$-allyl complexes $\mathbf{3}$, although compounds of these two types have the same formula according to mass and elemental analyses. In addition to an $v(\mathrm{CO})$ absorption band in the $1650-1600 \mathrm{~cm}^{-1}$ region, there are two terminal $\mathrm{W}-\mathrm{CO}$ stretching frequencies ( $v(\mathrm{CO}) \mathrm{ca} .2000$ and $1930 \mathrm{~cm}^{-1}$ ) for compounds 4-7, and these values are much larger than those ( $v$ (CO) 1940 and $1870 \mathrm{~cm}^{-1}$ ) of compound 3.7,8 This information suggests that a new carbonylation reaction occurs in the reaction of water or amine with the aged solution of ' $\mathbf{D}^{\prime}$. In contrast, the reaction of $\mathrm{MeOH}$ with the same aged solution $\mathbf{D}^{\prime}$ did not produce any neutral organometall ic product. It is very difficult to deduce the structures of 4-7 based on their spectral data alone. Characterization of the structures relies on an X-ray diffraction study of compound $5 .^{9}$ Figure 1 shows the ORTEP drawing for its molecular structure, which reveals that $\mathrm{CpW}(\mathrm{CO})_{2}$ fragment is bound to an $\alpha$-hydroxycarbonyl alkene moiety in a $\eta^{1}, \eta^{2}$ fashion. The C(4) carbon of 5 becomes an $\mathrm{sp}^{3}$-hydridized carbon, whereas the $C(5)-C(6)$ carbon resembles a coordinated olefin, as shown by the $C(4)-C(5)(1.514 \AA)$ and $C(5)-C(6)(1.402$ $\AA$ ) bond lengths. The arrangement of the $C(4)-C(5)-$ $\mathrm{C}(6)-\mathrm{N}$ atoms of $\mathbf{5}$ is close to a $\mathrm{U}$-shaped conformation, with the $\mathrm{W}-\mathrm{C}(5)$ bond trans to the $\mathrm{C}(6)-\mathrm{Ph}$ bond to minimize its steric hindrance. Only one single diastereomer was observed for compounds 4-7, and the lack of the other diastereomer is probably due to its sterically congested structure because it is shown later that anal ogous diastereomers can undergo mutual exchange at room temperature (vide infra). We also investigated this reaction with chiral $(R)$-methylbenzylamine with an aged acidification solution of compound $\mathbf{2}$, and two optically pure diastereomers $\mathbf{8 a}$ and $\mathbf{8 b}$ were produced

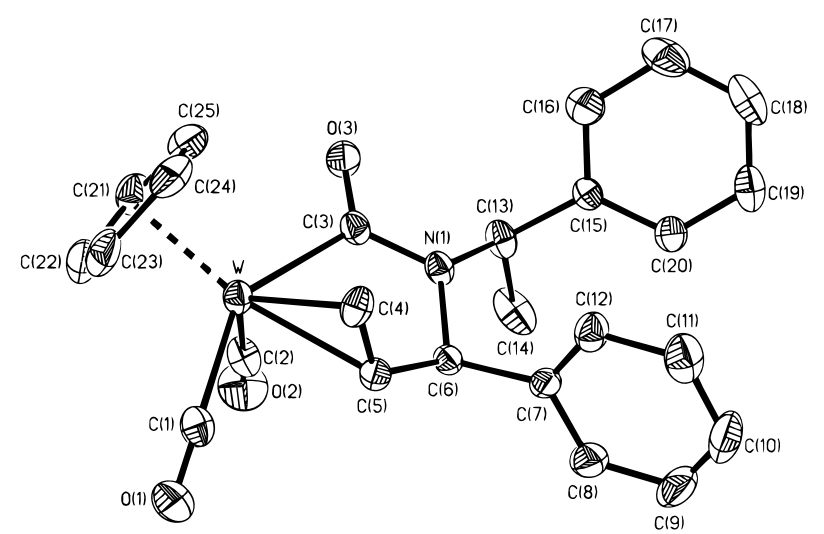

Figure 2. Molecular structure of compound $\mathbf{8 b}$ with selected bond distances $(\AA)$ and angles (deg): $W-C(3)=$ $2.240(5), W-C(5)=2.299(5), W-C(4)=2.240(4), C(3)-$ $\mathrm{O}(3)=1.235(6), \mathrm{C}(3)-\mathrm{N}(1)=1.376(6), \mathrm{C}(6)-\mathrm{N}(1)=1.458-$ (6), $C(5)-C(6)=1.518(6), C(4)-C(5)=1.400(7)$.

and further separated on a silica column to give $28 \%$ and $29 \%$ yiel ds, respectively. Both $\mathbf{8 a}$ and $\mathbf{8 b}$ presumbly have the same configuration $\left(2 \mathrm{~S}^{*}, 3 \mathrm{~S}^{*}\right)$ at the two $\mathrm{C}^{2} \mathrm{H}-$ $\mathrm{C}^{3} \mathrm{HPh}$ carbons because the magnitudes of the coupling constant $\left(\mathrm{J}_{23}=2.9-3.0 \mathrm{~Hz}\right)$ are very close to those $\left(\mathrm{J}_{23}\right.$ $=2.8-3.3 \mathrm{~Hz}$ ) of compounds $4-7$. The $X$-ray structure ${ }^{10}$ of chiral compound $\mathbf{8 b}$ is shown in Figure 2 , which confirms the proposed configurations at the C(5) and $C(6)$ carbons as that of compound 5. Similarly, the $\mathrm{W}-\mathrm{C}(5)$ bond of $\mathbf{8 b}$ is trans to the $\mathrm{C}(6)-\mathrm{Ph}$ group to minimize steric interactions.

We attempted to characterize the proposed tungsten$\eta^{2}$-cis-allene cation (D) generated from $\mathbf{2}$ as well as the species in its aged solution $\mathbf{D}^{\prime}$. Protonation of $\mathrm{CpM}(\mathrm{CO})_{3^{-}}$ $\left(\eta^{1}-\mathrm{CH}_{2} \mathrm{C} \equiv \mathrm{CR}\right)(\mathrm{M}=\mathrm{Mo}, \mathrm{W})^{7,8}$ with strong acid is believed to yield $\eta^{2}$-cis-allene species initially, but its NMR characterization is not yet reported. Addition of excess anhydrous diethyl ether to the two solution gave two dark black solids D and ' ', respectively, which were virtually insoluble in polar solvents such as $\mathrm{CH}_{2} \mathrm{Cl}_{2}$, $\mathrm{CHCl}_{3}$, and $\mathrm{CH}_{3} \mathrm{CN}$. We therefore prepared $\mathrm{Cp} * \mathrm{~W}(\mathrm{CO})_{3^{-}}$ $\left(\eta^{1}-\mathrm{CH}_{2} \mathrm{C} \equiv \mathrm{CPh}\right)^{11}\left(\mathrm{Cp}^{*}=\mathrm{C}_{5} \mathrm{Me}_{5}\right)(\mathbf{9})$ because pentamethylcyclopentadienylmetal complexes are usually more solubl $\mathrm{e}^{12}$ than their cyclopentadienylmetal analogues. Scheme 3 shows the outcome for the same reaction sequence.

Similar to its cyclopentadienyl analogue $\mathbf{1}$ and $\mathbf{2}$, compounds $\mathbf{1 0}$ and $\mathbf{1 1 a , b}$ are obtained in $85 \%$ and $56 \%$ yiel ds, respectively, via water treatment of the fresh (D) and the aged ( $\left.\mathbf{D}^{\prime}\right)$ solution of $\mathbf{9}$ after acidification with triflic acid. The diastereoisomeric ratio of $\mathbf{1 1 a}$ and $\mathbf{1 1 b}$ was ca. 3:1; these two isomers could undergo mutual exchange (videinfra) at el evated temperatures. Addition of benzylamine to the aged solution ' $\mathbf{D}^{\prime}$ of $\mathbf{9}$ also gave the new carbonylation product $\mathbf{1 2}$ as a single diastereomer in $49 \%$ yield. The stereochemistry of $\mathbf{1 2}$ is assigned

(9) Crystal data for 5: monoclinic space group, P21/n, a $=6.4197$ (20) $\AA, b=11.2660(14) \AA, c=20.658(3) \AA, \beta=95.27(3)^{\circ}, V=1487.7$ (5) $\AA^{3}, Z=4$. Of the 2621 unique reflections, 2181 were considered observed having I $>2 \sigma(\mathrm{I})$. Final $\mathrm{R}=0.020, \mathrm{R}_{\mathrm{w}}=0.020$.

(10) Crystal data for $\mathbf{8 b}$ : monodinic space group, $\mathrm{P} 2{ }_{1} 2_{1} 2_{1}$, a $=$ $12.1514(2) \AA, b=13.2603(2) \AA, c=13.5770(3) \AA, V=2187.68(7) \AA^{3}$ $\mathrm{Z}=4$. Of the 13374 unique reflections, 5021 were considered observed having $\mathrm{I}>2 \sigma(\mathrm{I})$. Final $\mathrm{R}=0.028, \mathrm{R}_{\mathrm{w}}=0.048$

(11) Bell, P. B.; Wojcicki, A. Inorg. Chem. 1981, 20, 1585

(12) Collman, J. P.; Hegedus, L. S.; Norton, J . R.; Finke, R. G. Principles and Application of Organotransition Metal Chemistry; University Science Books: Mill Valley, CA, 1987; Chapter 3, p 165. 
Scheme 2

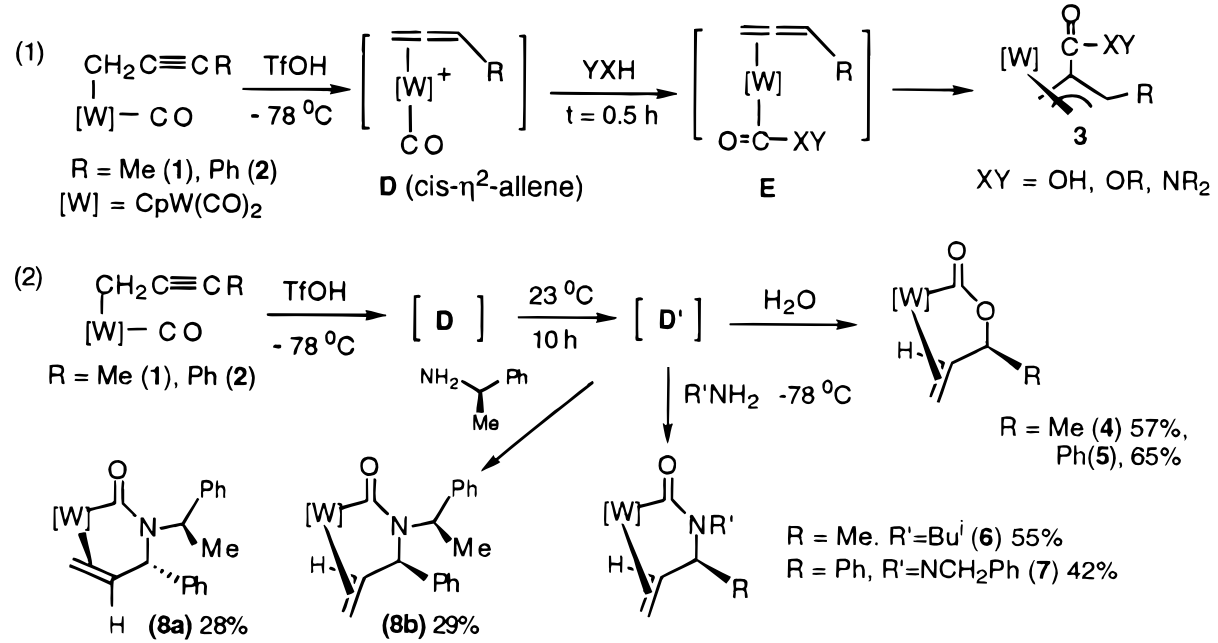

Scheme 3

(1)

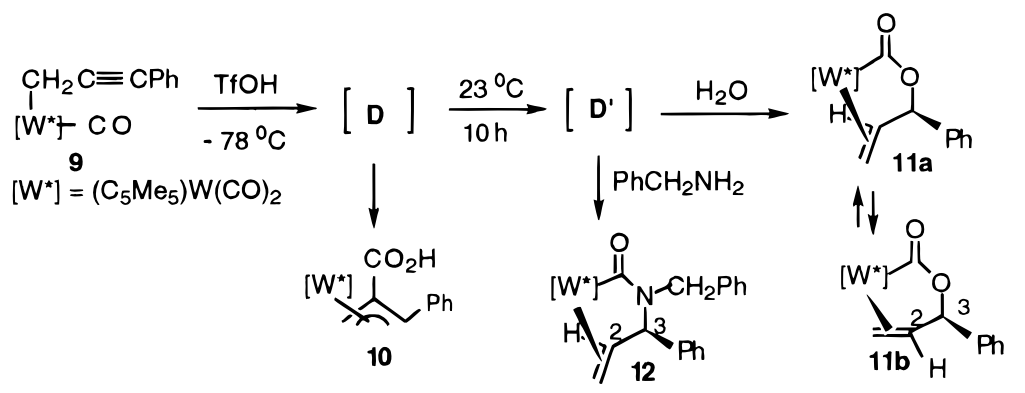

(2)

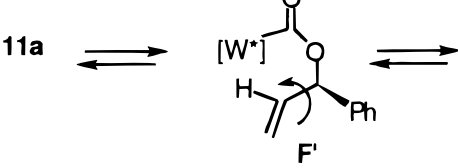<smiles>C#CC(=O)O[C@H](C(=C)[AlH2])c1ccccc1</smiles><smiles>O=C1O[C@H](c2ccccc2)[C@H]2C[C@H]1N[C@H]2O</smiles>

to have the $\left(2 R^{*}, 3 R^{*}\right)$ configuration as inferred from the coupling constant J $23=3.4 \mathrm{~Hz}$. Attempts to obtain the NMR spectral data of the solid forms precipitated from the solutions $\mathbf{D}$ and $\mathbf{D}^{\prime}$ were still unsuccessful due to their poor solubility in common solvents. We are aware that solid samples $\mathbf{D}$ and $\mathbf{D}^{\prime}$ have different chemical properties compared to the solution species in mother $\mathrm{CH}_{2} \mathrm{Cl}_{2}$. For instance, treatment of the two solid samples with water gave compounds $\mathbf{1 0}$ and $\mathbf{1 1 a}$ in $38 \%$ and $12 \%$ yields, respectively; the yield was very low, particularly for $\mathbf{D}^{\prime}$. It is likely that the species in these two phases are not the same.

Figure 3 shows variable-temperature ${ }^{1} \mathrm{H}$ NMR spectra for the two diastereomers $\mathbf{1 1 a}$ and $\mathbf{1 1 b}$ in $\mathrm{CDCl}_{3}$. The major diastereomer 11 a is assigned to have the $(2 \mathrm{R} *$, $3 R^{*}$ ) configuration based on the proton coupling constant J $23=2.9 \mathrm{~Hz}$ and the chemical shift of $\mathrm{C}^{2} \mathrm{H}(\delta 4.12$ $\mathrm{ppm})$, which are close to those $\left(\mathrm{J}_{23}=3.0 \mathrm{~Hz}\right.$ and $\mathrm{C}^{2} \mathrm{H} \delta$ $4.00 \mathrm{ppm}$ ) of compound $\mathbf{5}$. The minor isomer $\mathbf{1 1 b}$ is assigned to have the $\left(2 \mathrm{R}^{*}, 3 \mathrm{~S}^{*}\right)$ configuration, and its proton parameters $\left(\mathrm{J}_{23}=0 . \mathrm{Hz}\right.$ and $\left.\mathrm{C}^{2} \mathrm{H} \delta 3.12 \mathrm{ppm}\right)$ are quite distinct from compounds $\mathbf{1 1 a}$ and $\mathbf{5}$. As the temperatures were raised from $-10^{\circ} \mathrm{C}$, the resonances become broad in the $40-50{ }^{\circ} \mathrm{C}$ range. Recooling the temperatures to $-10{ }^{\circ} \mathrm{C}$ regenerates the well-defined spectra of the two species. Attempts to raise the temperatures above $60^{\circ} \mathrm{C}$ led to rapid decomposition of the compound. A proton spin transfer experiment also supported the exchange process. I rradiation of the $\mathrm{C}^{2} \mathrm{H}$

proton signal ( $\delta 3.12 \mathrm{ppm}$ ) of $\mathbf{1 1 b}$ showed a complete disappearance of the $\mathrm{C}^{2} \mathrm{H}$ proton signal $(\delta 4.12 \mathrm{ppm})$ of 11a. Scheme 3 (eq 2) shows the mechanism for mutual exchange of these two species. We propose the mechanism in Scheme 3, which involves dissociation of the $C=$ $\mathrm{C}$ double bond of 11a from the tungsten center to form the 16 e species $\mathbf{F}^{\prime}$. Subsequent rotation of the $C^{2}-C^{3}$ single bond of $\mathbf{F}^{\prime}$ gives another conformer $\mathbf{F}^{\prime \prime}$, and finally compound $\mathbf{1 1 b}$.

One unanswered issue is the alternation of chemoselectivity for the fresh and aged solution of tungsten$\eta^{1}$-propargyl complexes after acidification with triflic acid. We did not have experimental data to elucidate the formation mechanism of the new carbonylation products 4-7, $\mathbf{8 a}, \mathbf{b}$, and $\mathbf{1 1} \mathbf{a}, \mathbf{b}$ because NMR characterization of the two solution species was unsuccessful. Neverthelss, a speculative mechanism is helpful to understand the nature of whole reaction sequence. It is reported earlier that protonation of $\mathrm{CpFe}(\mathrm{CO})_{2}\left(\eta^{1-}\right.$ $\mathrm{CH}_{2} \mathrm{C} \equiv \mathrm{CPh}$ ) with $\mathrm{HPF}_{6}{ }_{6}{ }^{\text {a }}$ in acetic anhydride gave cis$\eta^{2}$-allene as the kinetic product, which was then isomerized to the more stable trans- $\eta^{2}$-allene species such as D' in Scheme 4 as the temperatures was raised. In Scheme 4, the fresh acidification solution of compounds $\mathbf{1}$ and $\mathbf{2}$ consisted exclusively of cis- $\eta^{2}$-allene species $\mathbf{D}$, which reacted with water to give syn- $\pi$-allyl complexes 3. In a prolonged reaction period, species $\mathbf{D}$ undergoes isomerization to give trans- $\eta^{2}$-allene $\mathbf{D}^{\prime}$ species via intermediate $\mathbf{D}^{\prime \prime} .{ }^{13}$ The $\mathrm{C}^{2}-\mathrm{C}^{3}$ bond of $\mathbf{D}^{\prime \prime}$ can be 


\section{Scheme 4}
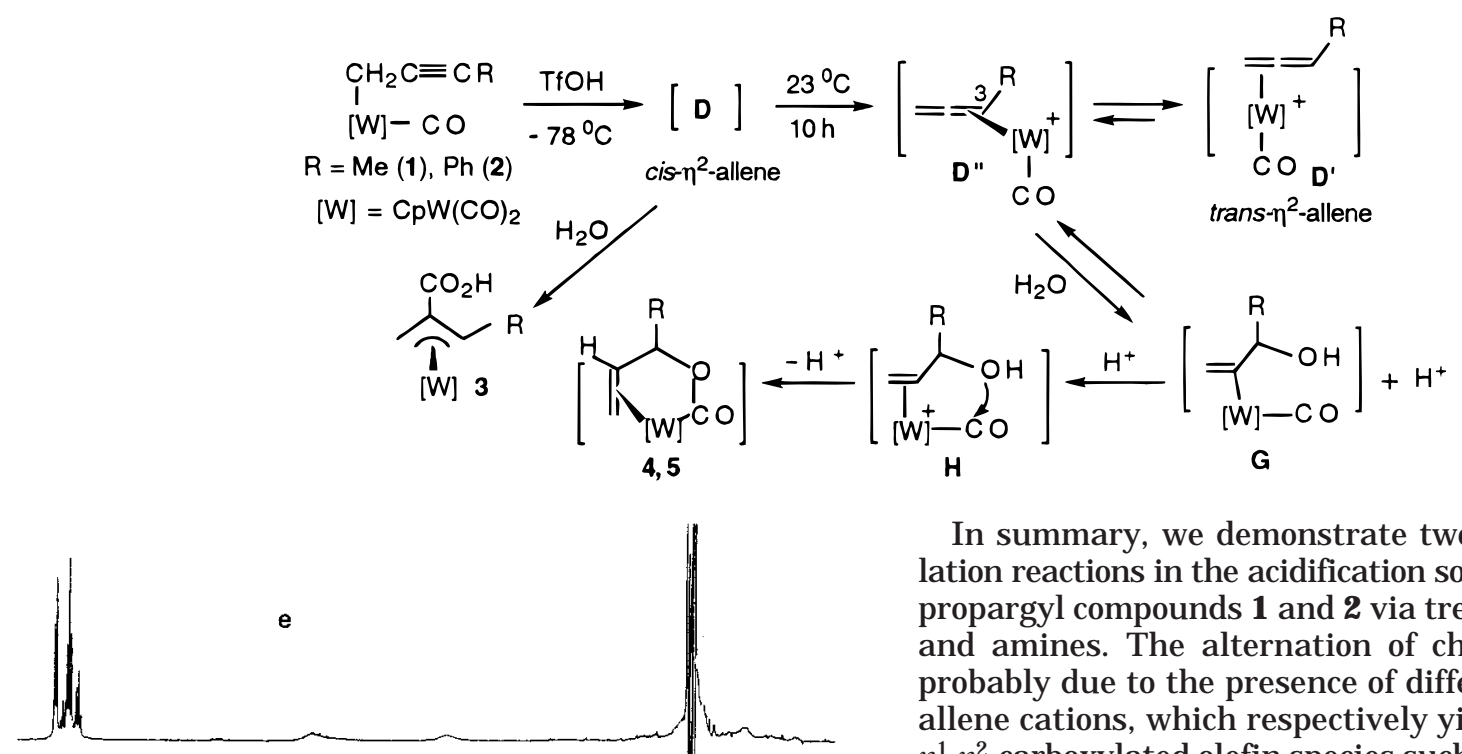

In summary, we demonstrate two types of carbonylation reactions in the acidification solution of tungstenpropargyl compounds $\mathbf{1}$ and $\mathbf{2}$ via treatment with water and amines. The alternation of chemoselectivities is probably due to the presence of different tungsten $-\eta^{2}$ allene cations, which respectively yield syn- $\pi$-allyl and $\eta^{1}, \eta^{2}$-carboxylated ol efin species such as $\mathbf{4 - 7}, \mathbf{8 a}, \mathbf{b}$, and 11a,b. We have characterized new carbonylation products $\mathbf{4}-\mathbf{7}, \mathbf{8 a}, \mathbf{b}$, and $\mathbf{1 1 a}, \mathbf{b}$ with appropriate physical methods including X-ray diffraction studies of the representative compounds $\mathbf{5}$ and $\mathbf{8 b}$. Variable-temperature ${ }^{1} \mathrm{H}$ NMR spectra show that the two diastereomers 11a and 11b can undergo mutual exchange at el evated temperatures; the mechanism of exchange is proposed to precede via dissociation of the coordinated ol efin to form a 16e species.

\section{Experimental Section}

Unless otherwise noted, all reactions were carried out under nitrogen atmosphere in oven-dried gl assware using standard syringe, cannula, and septa apparatus. Benzene, diethyl ether, tetrahydrofuran, and hexane were dried with sodium benzophenone and distilled before use. Dichloromethane was dried over $\mathrm{CaH}_{2}$ and distilled before use. W(CO) $)_{6}$, dicyclopentadiene, propargyl alcohol, and sodium were obtained commercially and used without purification. Tungsten propargyl compounds $\mathbf{1}$, $\mathbf{2}$, and $\mathbf{9}$ were prepared according to the procedures in the literature. ${ }^{7 a, 11}$

Synthesis of Compound 4. To a $\mathrm{CH}_{2} \mathrm{Cl}_{2}$ solution ( $15 \mathrm{~mL}$ ) of compound $\mathbf{1}\left(200 \mathrm{mg}, 0.52 \mathrm{mmol}\right.$ ) was added $\mathrm{CF}_{3} \mathrm{SO}_{3} \mathrm{H}$ (160 $\mathrm{mg}, 1.05 \mathrm{mmol}$ ) at $-78{ }^{\circ} \mathrm{C}$, and the mixture was stirred for 1 $\mathrm{h}$ before the reaction mixture was slowly warmed to room temperature over $12 \mathrm{~h}$. The solution was recooled to $-78^{\circ} \mathrm{C}$ and treated with saturated $\mathrm{NaHCO}_{3}(5.0 \mathrm{~mL})$ solution. The mixture was warmed to $23{ }^{\circ} \mathrm{C}$ and the organic layer was extracted with diethyl ether twice $(15 \mathrm{~mL})$. The combined organic extract was dried in vacuo and chromatographed on a silica column to yield compound $\mathbf{4}$ as a yellow solid ( $120 \mathrm{mg}$, $0.29 \mathrm{mmol}, 57 \%)$. IR $\left(\mathrm{CH}_{2} \mathrm{Cl}_{2}, \mathrm{~cm}^{-1}\right): v(\mathrm{~W}-\mathrm{CO}) 2003(\mathrm{~s}) ; 1930-$ (s); 1639 (br s). ${ }^{1} \mathrm{H} \mathrm{NMR}\left(\mathrm{CDCl}_{3}, 300 \mathrm{MHz}\right): \delta 5.45(5 \mathrm{H}, \mathrm{s}, \mathrm{Cp})$, $4.54\left(1 \mathrm{H}, \mathrm{m}, \mathrm{C}^{3} \mathrm{H}\right), 3.82\left(1 \mathrm{H}, \mathrm{m}, \mathrm{C}^{2} \mathrm{H}\right), 2.32(1 \mathrm{H}, \mathrm{d}, \mathrm{J}=6.3 \mathrm{~Hz}$, $\left.\mathrm{C}^{1} \mathrm{H}\right), 2.18\left(1 \mathrm{H}, \mathrm{d}, \mathrm{J}=7.2 \mathrm{~Hz}, \mathrm{C}^{1} \mathrm{H}\right), 1.46(3 \mathrm{H}, \mathrm{d}, \mathrm{J}=6.1 \mathrm{~Hz}$, Me). ${ }^{13} \mathrm{C} \mathrm{NMR}\left(\mathrm{CDCl}_{3}, 100 \mathrm{MHz}\right): \delta 220.4,214.0,209.1,90.9$, 73.4, 73.2, 22.5, 16.0. MS (EI; $75 \mathrm{eV} / \mathrm{m}): 404\left(\mathrm{M}^{+}\right)$. Anal. Calcd for $\mathrm{C}_{12} \mathrm{H}_{12} \mathrm{WO}_{4}$ : C, 35.67; $\mathrm{H}, 2.99$. Found: $\mathrm{C}, 35.34 ; \mathrm{H}, 3.13$.

Sythesis of Compound 5. To a $\mathrm{CH}_{2} \mathrm{Cl}_{2}(15 \mathrm{~mL})$ solution of compound 2 ( $200 \mathrm{mg}, 0.45 \mathrm{mmol}$ ) at $-78^{\circ} \mathrm{C}$ was added $\mathrm{CF}_{3-}$ $\mathrm{SO}_{3} \mathrm{H}(134 \mathrm{mg}, 0.89 \mathrm{mmol})$, and the mixture was stirred for 1 $\mathrm{h}$ before it was slowly warmed to $23^{\circ} \mathrm{C}$ over $12 \mathrm{~h}$. The reaction mixture was recooled to $-78{ }^{\circ} \mathrm{C}$ and treated with $\mathrm{NaHCO}_{3}$ $(3.0 \mathrm{~mL})$, and the mixture was warmed to $23^{\circ} \mathrm{C}$ over $6 \mathrm{~h}$. The organic layer was extracted with diethyl ether $(15 \mathrm{~mL})$ and evaporated under reduced pressure. The crude product was chromatographed on a silica col umn to yield compound $\mathbf{5}$ as a 
yellow solid (130 mg, $0.27 \mathrm{mmol}, 65 \%)$. IR $\left(\mathrm{CH}_{2} \mathrm{Cl}_{2}, \mathrm{~cm}^{-1}\right)$ : v(W-CO) 2012(s), 1946(s), 1648. ${ }^{1} \mathrm{H}$ NMR $\left(\mathrm{CDCl}_{3}, 400 \mathrm{MHz}\right)$ : $\delta 7.43-7.23(5 \mathrm{H}, \mathrm{m}, \mathrm{Ph}), 5.51(5 \mathrm{H}, \mathrm{s}, \mathrm{Cp}), 5.45(1 \mathrm{H}, \mathrm{d}, \mathrm{J}=2.8$ $\left.\mathrm{Hz}, \mathrm{C}^{3} \mathrm{H}\right), 4.00\left(1 \mathrm{H}, \mathrm{m}, \mathrm{C}^{2} \mathrm{H}\right), 2.32\left(1 \mathrm{H}, \mathrm{d}, \mathrm{J}=7.8 \mathrm{~Hz}, \mathrm{C}^{1} \mathrm{HH}^{\prime}\right)$, $2.30\left(1 \mathrm{H}, \mathrm{d}, \mathrm{J}=7.8 \mathrm{~Hz}, \mathrm{C}^{1} \mathrm{HH}^{\prime}\right) .{ }^{13} \mathrm{C} \mathrm{NMR}\left(\mathrm{CDCl}_{3}, 100 \mathrm{MHz}\right):$ $\delta$ 219.9, 214.0, 207.8, 141.7, 128.4, 127.8, 126.2, 91.1, 79.0, 72.2, 15.9; MS (El; $75 \mathrm{eV} / \mathrm{m})$ : $466\left(\mathrm{M}^{+}\right)$. Anal. Calcd for $\mathrm{C}_{17} \mathrm{H}_{14-}$ $\mathrm{WO}_{4}$ : C, 43.80; $\mathrm{H}, 3.03$. Found: $\mathrm{C}, 43.70 ; \mathrm{H}, 3.02$

Synthesis of Compound 6. To a $\mathrm{CH}_{2} \mathrm{Cl}_{2}$ solution ( $15 \mathrm{~mL}$ ) of compound $\mathbf{1}$ ( $200 \mathrm{mg}, 0.52 \mathrm{mmol}$ ) at $-78^{\circ} \mathrm{C}$ was added $\mathrm{CF}_{3-}$ $\mathrm{SO}_{3} \mathrm{H}(160 \mathrm{mg}, 1.05 \mathrm{mmol}$ ), and the mixture was stirred for 1 $\mathrm{h}$ and then slowly warmed to $23^{\circ} \mathrm{C}$ over $12 \mathrm{~h}$. The reaction mixture was recooled to $-78{ }^{\circ} \mathrm{C}$ and treated with isobutylamine $(73.6 \mathrm{mg}, 1 \mathrm{mmol})$. The sol ution was warmed to $23^{\circ} \mathrm{C}$ with rapid stirring for $6 \mathrm{~h}$. The organic material was extracted with diethyl ether $(15 \mathrm{~mL})$ and evaporated to dryness under reduced pressure. The crude product was then purified on a silica column to yield compound 6 as a yellow solid (130 mg, $0.28 \mathrm{mmol}, 55 \%)$. IR $\left(\mathrm{CH}_{2} \mathrm{Cl}_{2}, \mathrm{~cm}^{-1}\right): v(\mathrm{CO})$ 1992(s), 1925(s), 1620(br s). ${ }^{1} \mathrm{H}$ NMR $\left(\mathrm{CDCl}_{3}, 400 \mathrm{MHz}\right): \delta 5.38(5 \mathrm{H}, \mathrm{s}, \mathrm{Cp})$, $3.76\left(1 \mathrm{H}, \mathrm{m}, \mathrm{C}^{3} \mathrm{H}\right), 3.66\left(1 \mathrm{H}, \mathrm{m}, \mathrm{C}^{2} \mathrm{H}\right), 3.46(1 \mathrm{H}, \mathrm{m}), 2.37(1 \mathrm{H}$, $\mathrm{m}), 2.32\left(1 \mathrm{H}, \mathrm{d}, \mathrm{J}=8.0 \mathrm{~Hz}, \mathrm{CHH}^{\prime}\right), 2.02(1 \mathrm{H}, \mathrm{d}, \mathrm{J}=7.1 \mathrm{~Hz}$, $\left.\mathrm{CHH}^{\prime}\right), 1.70\left(1 \mathrm{H}, \mathrm{m}, \mathrm{CHMe}_{2}\right), 1.37(3 \mathrm{H}, \mathrm{d}, \mathrm{J}=6.3 \mathrm{~Hz}, \mathrm{Me})$, $0.80(3 \mathrm{H}, \mathrm{d}, \mathrm{J}=3.2 \mathrm{~Hz}, \mathrm{Me}), 0.74(3 \mathrm{H}, \mathrm{d}, \mathrm{J}=3.2 \mathrm{~Hz}, \mathrm{Me}) .{ }^{13} \mathrm{C}$ NMR $\left(\mathrm{CDCl}_{3}, 300 \mathrm{MHz}: \delta 225.2,217.1,205.7,91.5,68.7,58.2\right.$, 48.8, 26.5, 24.2, 19.9, 18.1. MS (EI, $75 \mathrm{eV} / \mathrm{m}): 458\left(\mathrm{M}^{+}\right)$. Anal. Calcd for $\mathrm{C}_{16} \mathrm{H}_{21} \mathrm{WO}_{3} \mathrm{~N}$ : C, 41.85; $\mathrm{H}, 4.61 ; \mathrm{N}, 3.05$. Found: $\mathrm{C}$, 41.88; $\mathrm{H}, 4.82 ; \mathrm{N}, 3.01$.

Synthesis of Compound 7. To a $\mathrm{CH}_{2} \mathrm{Cl}_{2}$ solution ( $15 \mathrm{~mL}$ ) of compound 2 ( $200 \mathrm{mg}, 0.45 \mathrm{mmol}$ ) at $-78{ }^{\circ} \mathrm{C}$ was added $\mathrm{CF}_{3^{-}}$ $\mathrm{SO}_{3} \mathrm{H}$ (134 mg, $0.89 \mathrm{mmol}$ ), and the mixture was stirred for 1 $\mathrm{h}$ before it was slowly warmed to $23^{\circ} \mathrm{C}$ over $12 \mathrm{~h}$. The reaction mixture was recooled to $-78^{\circ} \mathrm{C}$ and treated with benzylamine (982 mg, $9.16 \mathrm{mmol}$ ). The mixture was kept stirring for $8 \mathrm{~h}$. The solution was then quenched with water and washed with saturated $\mathrm{NH}_{4} \mathrm{Cl}$ solution. The organic material was extracted with diethyl ether ( $15 \mathrm{~mL})$. The combined organic extract was dried and evaporated under reduced pressure.The crude product was then purified using preparative TLC (diethyl ether/hexane, $1: 1$ ) to yield compound 7 as a yellow solid (100 $\mathrm{mg}, 0.18 \mathrm{mmol}, 42 \%)$, IR $\left(\mathrm{CH}_{2} \mathrm{Cl}_{2}, \mathrm{~cm}^{-1}\right)$ : 1992(s), 1925(s), 1638(br). ${ }^{1} \mathrm{H}$ NMR $\left(\mathrm{CDCl}_{3}, 300 \mathrm{MHz}\right): \delta 7.32-7.26(2 \mathrm{H}, \mathrm{m}$, $\mathrm{Ph}), 7.12-7.08$ (6H, m, Ph), 6.78 (2H, m, Ph), 5.47 (5H, s, Cp), $5.23(1 \mathrm{H}, \mathrm{d}, \mathrm{J}=13.0 \mathrm{~Hz}, \mathrm{NCHH}),, 4.39(1 \mathrm{H}, \mathrm{d}, \mathrm{J}=3.2 \mathrm{~Hz}$, $\left.\mathrm{C}^{3} \mathrm{H}\right)$, $3.71\left(1 \mathrm{H}, \mathrm{m}, \mathrm{C}^{2} \mathrm{H}\right), 3.10\left(\mathrm{H}, \mathrm{d}, \mathrm{J}=13.0 \mathrm{~Hz}, \mathrm{NCHH}^{\prime}\right)$, $2.45\left(1 \mathrm{H}, \mathrm{d}, \mathrm{J}=6.9 \mathrm{~Hz}, \mathrm{C}^{1} \mathrm{HH}^{\prime}\right), 2.27(1 \mathrm{H}, \mathrm{d}, \mathrm{J}=6.6 \mathrm{~Hz}$, $\left.\mathrm{C}^{1} \mathrm{HH}^{\prime}\right) .{ }^{13} \mathrm{C} \mathrm{NMR}\left(\mathrm{CDCl}_{3}, 100 \mathrm{MHz}\right): \delta 223.4,216.0,207.0$ $143.2,132.6,128.7,128.4,128.2,127.2,127.8,127.7,127.6$, 126.6, 91.4, 68.1, 64.8, 45.2, 17.7. MS (EI, $75 \mathrm{eV} / \mathrm{m}): 550\left(\mathrm{M}^{+}\right)$. Anal. Calcd for $\mathrm{C}_{24} \mathrm{H}_{21} \mathrm{WNO}_{3}$ : C, 51.91; $\mathrm{H}, 3.81 ; \mathrm{N}, 2.52$. Found: C, 52.49; H, 3.97; N, 2.50.

Synthesis of Compounds $8 \mathbf{a}$ and 8 b. To a $\mathrm{CH}_{2} \mathrm{Cl}_{2}$ solution (15.0 mL) of compound 2 ( $200 \mathrm{mg}, 0.45 \mathrm{mmol}$ ) at $-78{ }^{\circ} \mathrm{C}$ was added $\mathrm{CF}_{3} \mathrm{SO}_{3} \mathrm{H}$ (134 mg, $0.89 \mathrm{mmol}$ ), and the mixture was stirred for $1 \mathrm{~h}$ before it was warmed to room temperature over $12 \mathrm{~h}$. The reaction mixture was recooled to $-78^{\circ} \mathrm{C}$ and treated with (R-(+)- $\alpha$-methylbenzylamine $(752 \mathrm{mg}, 6.2 \mathrm{mmol})$. The solution was warmed to $23^{\circ} \mathrm{C}$ over $24 \mathrm{~h}$ before treatment with saturated $\mathrm{NH}_{4} \mathrm{Cl}$ solution $(3.0 \mathrm{~mL}$ ). The organic layer was separated, concentrated, and purified on a silica column to yield compounds $\mathbf{8 a}$ (71 mg, $0.12 \mathrm{mmol}, 27 \%$ ) and $\mathbf{8 b}$ (71 mg, $0.25 \mathrm{mmol}, 28 \%)$, respectively.

Spectral Data for 8a: IR $\left(\mathrm{CH}_{2} \mathrm{Cl}_{2}, \mathrm{~cm}^{-1}\right)$ : 1995(s), 1928(s), $1641(\mathrm{br}) .{ }^{1} \mathrm{H}$ NMR $\left(\mathrm{CDCl}_{3}, 400 \mathrm{MHz}\right): \delta 7.14-7.04(8 \mathrm{H}$, $\mathrm{m}, \mathrm{Ph}), 6.81(2 \mathrm{H}, \mathrm{d}, \mathrm{J}=5.8 \mathrm{~Hz}, \mathrm{Ph}), 5.45(5 \mathrm{H}, \mathrm{s}, \mathrm{Cp}), 5.12$ $(1 \mathrm{H}, \mathrm{m}, \mathrm{NCH}), 4.37\left(1 \mathrm{H}, \mathrm{d}, \mathrm{J}=3.0 \mathrm{~Hz}, \mathrm{C}^{3} \mathrm{H}\right), 3.73(1 \mathrm{H}, \mathrm{m}$, $\left.\mathrm{C}^{2} \mathrm{H}\right), 2.55\left(1 \mathrm{H}, \mathrm{d}, \mathrm{J}=8.0 \mathrm{~Hz}, \mathrm{C}^{1} \mathrm{HH}^{\prime}\right), 2.29(1 \mathrm{H}, \mathrm{d}, \mathrm{J}=8.4 \mathrm{~Hz}$, $\left.\mathrm{C}^{1} \mathrm{HH}\right), 1.05(3 \mathrm{H}, \mathrm{d}, \mathrm{J}=7.2 \mathrm{~Hz}, \mathrm{Me}) .{ }^{13} \mathrm{C} \mathrm{NMR}\left(\mathrm{CDCl}_{3}, 75\right.$ $\mathrm{MHz}): \delta 224.1,216.7,206.0$ 144.1, 140.6, 128.6, 127.8, 127.7, 126.2, $91.6(\mathrm{Cp}), 68.1,65.6,51.0,17.9,17.3 . \mathrm{MS}\left(\mathrm{EI}^{+}, 75 \mathrm{eV} /\right.$ m): $569\left(\mathrm{M}^{+}\right) .[\alpha]_{D}{ }^{25}=-6.3\left(\mathrm{c}=1.0, \mathrm{CH}_{2} \mathrm{Cl}_{2}\right)$. Anal. Cal cd for $\mathrm{C}_{25} \mathrm{H}_{23} \mathrm{WNO}_{3}$ : C, 52.74; $\mathrm{H}, 4.07 ; \mathrm{N}, 2.46$. Found: $\mathrm{C}, 52.63 ; \mathrm{H}$, 4.28; N, 2.53 .
Spectral Data for 8b: IR $\left(\mathrm{CH}_{2} \mathrm{Cl}_{2}, \mathrm{~cm}^{-1}\right)$ : 1995(s), 1926(s), 1642(br). ${ }^{1} \mathrm{H}$ NMR $\left(\mathrm{CDCl}_{3}, 400 \mathrm{MHz}\right): \delta 7.44-7.27(\mathrm{~m}, 9 \mathrm{H}$, $\mathrm{Ph}), 7.12(1 \mathrm{H}, \mathrm{d}, \mathrm{J}=2.8 \mathrm{~Hz}, \mathrm{Ph}), 5.66(5 \mathrm{H}, \mathrm{s}, \mathrm{Cp}), 5.09(1 \mathrm{H}$, $m, \mathrm{NCH}), 5.02\left(1 \mathrm{H}, \mathrm{d}, \mathrm{J}=2.9 \mathrm{~Hz}, \mathrm{C}^{3} \mathrm{H}\right), 3.87\left(1 \mathrm{H}, \mathrm{m}, \mathrm{C}^{2} \mathrm{H}\right)$, $2.71(1 \mathrm{H}, \mathrm{d}, \mathrm{J}=10.0 \mathrm{~Hz}), 2.49\left(1 \mathrm{H}, \mathrm{d}, \mathrm{J}=8.4 \mathrm{~Hz}, \mathrm{CHH}^{\prime}\right), 1.64$ $\left(3 \mathrm{H}, \mathrm{d}, \mathrm{J}=7.2 \mathrm{~Hz}, \mathrm{CHH}^{\prime}\right) .{ }^{13} \mathrm{C} \mathrm{NMR}\left(\mathrm{CDCl}_{3}, 75 \mathrm{MHz}\right): \delta 224.0$, 216.3, 206.5, 143.6, 143.2, 128.7, 127.6, 127.5, 127.4, 91.7, 67.5, 66.4, 51.4, 17.3, 16.6. MS (El+, $75 \mathrm{eV} / \mathrm{m}): 569\left(\mathrm{M}^{+}\right) .[\alpha]_{D} 25=$ 98.6 ( $\mathrm{c}=1.0, \mathrm{CH}_{2} \mathrm{Cl}_{2}$ ). Anal. Calcd for $\mathrm{C}_{25} \mathrm{H}_{23} \mathrm{WNO}_{3}$ : C, 52.74; $\mathrm{H}, 4.07$; N, 2.46. Found: C, 52.55; H, 4.18; N, 2.51 .

Synthesis of Compounds 11a and 11b. To a $\mathrm{CH}_{2} \mathrm{Cl}_{2}$ solution $(15.0 \mathrm{~mL})$ of compound $\mathbf{9}(200 \mathrm{mg}, 0.38 \mathrm{mmol})$ at $78{ }^{\circ} \mathrm{C}$ was added $\mathrm{CF}_{3} \mathrm{SO}_{3} \mathrm{H}$ ( $115.8 \mathrm{mg}, 0.77 \mathrm{mmol}$ ), and the mixture was stirred for $1 \mathrm{~h}$ before it was warmed to room temperature over $12 \mathrm{~h}$. The reaction mixture was recooled to $-78{ }^{\circ} \mathrm{C}$ and treated with saturated $\mathrm{NaHCO}_{3}$ solution. This cold solution was warmed to $23{ }^{\circ} \mathrm{C}$ over $24 \mathrm{~h}$ with rapid stirring. The organic layer was separated, concentrated, and purified on a silica column to yield compounds $\mathbf{1 1 a}$ and $\mathbf{1 1 b}$ as yell ow solids (116 mg, $0.21 \mathrm{mmol}, 56 \%, \mathbf{1 1 a} / \mathbf{1 1 b}=3: 1)$. IR $\left(\mathrm{CH}_{2} \mathrm{Cl}_{2}\right.$, $\mathrm{cm}^{-1}$ ): 1995(s), 1928(s), 1637 (br). ${ }^{1} \mathrm{H} \mathrm{NMR}\left(\mathrm{CDCl}_{3}, 400\right.$ $\mathrm{MHz})$ : for 11a, $\delta 7.45-7.30(10 \mathrm{H}, \mathrm{m}), 5.36(1 \mathrm{H}, \mathrm{d}, \mathrm{J}=2.9 \mathrm{~Hz}$, $\left.\mathrm{C}^{3} \mathrm{H}\right), 4.12\left(1 \mathrm{H}, \mathrm{m}, \mathrm{C}^{2} \mathrm{H}\right), 2.10(15 \mathrm{H}, \mathrm{Me}), 2.00(1 \mathrm{H}, \mathrm{d}, \mathrm{J}=6.0$ $\left.\mathrm{Hz}, \mathrm{C}^{1} \mathrm{HH}^{\prime}\right), 1.60\left(1 \mathrm{H}, 1 \mathrm{H}, \mathrm{d}, \mathrm{J}=6.0 \mathrm{~Hz}, \mathrm{C}^{1} \mathrm{HH}^{\prime}\right)$, for $\mathbf{1 1 b}, \delta$ 7.45-7.30 (10H , m), $4.95\left(1 \mathrm{H}, \mathrm{s}, \mathrm{C}^{3} \mathrm{H}\right), 3.12\left(1 \mathrm{H}, \mathrm{m}, \mathrm{C}^{2} \mathrm{H}\right), 2.14$ $(15 \mathrm{H}, \mathrm{Me})$, the two $\mathrm{C}^{1} \mathrm{H}_{2}$ proton resonances were masked by those of pentamethyl groups. ${ }^{13} \mathrm{C} \mathrm{NMR}(\mathrm{CDCl} 3,100 \mathrm{MHz})$ : 11a, 227.2, 218.0, 211.5, 142.0, 128.2, 127.6, 126.2, 103.1, 78.4 75.7, 25.5, 10.6; 11b, 222.0, 211.5, 208.8, 142,5, 128.5, 127,4, $125.7,101.5,79.8,50.7,33.4,10.6$. Anal. Calcd for $\mathrm{C}_{22} \mathrm{H}_{24} \mathrm{WO}_{4}$ : C, 49.27; $\mathrm{H}, 4.51$. Found: $C, 49.68 ; \mathrm{H}, 4.56$.

Synthesis of Compound 12. To a $\mathrm{CH}_{2} \mathrm{Cl}_{2}$ solution (15.0 $\mathrm{mL}$ ) of compound $\mathbf{9}(200 \mathrm{mg}, 0.38 \mathrm{mmol})$ at $-78{ }^{\circ} \mathrm{C}$ was added $\mathrm{CF}_{3} \mathrm{SO}_{3} \mathrm{H}$ (116 mg, $0.77 \mathrm{mmol}$ ), and the mixture was stirred for $1 \mathrm{~h}$ before it was warmed to room temperature over $12 \mathrm{~h}$. The reaction mixture was recool ed to $-78^{\circ} \mathrm{C}$ and treated with benzylamine $(2.0 \mathrm{~mL})$. This cold solution was stirred and warmed to $23^{\circ} \mathrm{C}$ over $24 \mathrm{~h}$. The organic layer was separated, concentrated, and purified on a silica column to yield compound 12 as yellow solid (118 mg, $0.18 \mathrm{mmol}, 49 \%)$. I R $\left(\mathrm{CH}_{2-}\right.$ $\mathrm{Cl}_{2}, \mathrm{Cm}^{-1}$ ): 1993(s), 1927(s), 1608 (br). ${ }^{1} \mathrm{H} \mathrm{NMR}\left(\mathrm{CDCl}_{3}, 400\right.$ $\mathrm{MHz}): \delta 7.35-7.10(8 \mathrm{H}, \mathrm{m}), 6.75-6.80(2 \mathrm{H}, \mathrm{br} \mathrm{s}, \mathrm{Ph}), 5.28$ $\left(1 \mathrm{H}, \mathrm{d}, \mathrm{J}=13.2 \mathrm{~Hz}, \mathrm{NCHH}^{\prime}\right), 4.20\left(1 \mathrm{H}, \mathrm{d}, \mathrm{J}=3.4 \mathrm{HzC}^{1} \mathrm{HH}^{\prime}\right)$, $3.88\left(1 \mathrm{H}, \mathrm{m}, \mathrm{C}^{2} \mathrm{H}\right), 3.13\left(1 \mathrm{H}, \mathrm{d}, \mathrm{J}=13.2 \mathrm{~Hz}, \mathrm{NCHH}^{\prime}\right), 2.10$ $(1 \mathrm{H}, \mathrm{s}, \mathrm{Me}), 1.56\left(1 \mathrm{H}, \mathrm{d}, \mathrm{J}=5.2 \mathrm{~Hz}, \mathrm{C}^{1} \mathrm{HH}^{\prime}\right) .{ }^{13} \mathrm{C} \mathrm{NMR}\left(\mathrm{CDCl}_{3}\right.$, $100 \mathrm{~Hz}$ ): $231.0,220.3,210.5,143.6,138.1,128.8,128.3,127.8$, 127.4, 126.4, 102.8, 71.7, 64.8, 45.0, 28.1, 10.5. MS (EI, $75 \mathrm{eV} /$ m): $625\left(\mathrm{M}^{+}\right)$. Anal. Calcd for $\mathrm{C}_{29} \mathrm{H}_{31} \mathrm{WNO}_{3}: \mathrm{C}, 55.69 ; \mathrm{H}, 4.02$. Found: C, 55.76; H, 4.14.

X-ray Diffraction Studies of $\mathbf{5}$ and $\mathbf{8 b}$. Single crystals of $\mathbf{5}$ and $\mathbf{8 b}$ were sealed in glass capillaries under an inert atmosphere. Data for $\mathbf{5}$ and $\mathbf{8 b}$ were collected on a N onius CAD 4 using graphite-monochromated Mo K $\alpha$ radiation. The structures of $\mathbf{5}$ and $\mathbf{8 b}$ were solved by the heavy-atom method, respectively; all data reduction and structural refinements were performed with the NRCCSDP package. Crystal data, details of data collection, and structural analysis of these three compounds are presented in the Supporting I nformation. For all structures, all nonhydrogen atoms were refined with anisotropic parameters, and all hydrogen atoms included in the structure factors were placed in idealized positions.

Acknowledgment. We gratefully acknowledge financial support of this work from the National Science Council, Republic of China.

Supporting Information Available: Tables of crystal data, atomic coordinates, and bond distances and angles of $\mathbf{5}$ and $\mathbf{8 b}$. This material is available free of charge via the Internet at http://pubs.acs.org.

OM980787Q 